\title{
Presence of Planktothrix sp. and Cyanobacterial Toxins in Lake Ammersee, Germany and their Impact on Whitefish (Coregonus lavaretus L.)
}

\author{
Bernhard Ernst, Bettina Hitzfeld, Daniel Dietrich \\ Environmental Toxicology, University of Konstanz, P.O. Box X918, 78457 Konstanz, Germany
}

\begin{abstract}
Due to the increasing oligotrophy of Lake Ammersee, southern Germany, metalimnic Planktothrix have become one of the dominant planktonic species causing regular blooms. Whitefish (Coregonus lavaretus) is the dominant local fish species with great importance for the fishing industry. Recently, whole age groups of this fish species have disappeared and since 1991, average body-weight has decreased. The causes for this remain unclear. Planktothrix species produce the cyclic peptide toxin desmethyl microcystin-RR, which inhibits glycogen metabolism and has detrimental effects on the development of aquatic organisms. During blooms, gut contents of whitefish displayed a blue discoloration, possibly representing phycobiliproteins typical for cyanobacteria. This study aimed to elucidate the impact of Planktothrix blooms on fish population dynamics. Planktothrix cell counts, performed by epifluorescence microscopy, showed blooms to contain up to 80,000 cells $/ \mathrm{ml}$. Microcystin levels of $1-5 \mu \mathrm{g} / \mathrm{mg}$ dry weight in Planktothrix extracts and $0.08 \mu \mathrm{g} / \mathrm{l}$ in water samples, were determined via HPLC and protein-phosphatase inhibition assay. Planktothrix filaments were detected in gut contents of whitefish. In addition, microcystins could be detected in gut contents via ELISA. Similarly, immunoprobing with microcystin-antibodies demonstrated microcystin-protein adducts in liver homogenates of whitefish caught during Planktothrix blooms. Furthermore, Planktothrix extracts proved cytotoxic to trout hepatocytes as determined by MTT reduction. Whitefish eggs and larvae, obtained during blooms in winter 1998 and 2000 in a Lake Ammersee hatchery, were studied for developmental progress. Malformations typical for cyanobacterial toxin exposure were observed.
\end{abstract}

Keywords: cyanobacteria; Planktothrix; microcystin; fish

\section{INTRODUCTION}

Due to the increasing oligotrophy of Lake Ammersee, southern Germany, the cyanobacteria Planktothrix rubescens/agardhii have become one of the dominant

Correspondence to: B. Ernst; e-mail: bernhard.ernst@unikonstanz.de.

Contract grant sponsor: Arthur and Aenne Feindt Foundation, Hamburg. planktonic species causing regular blooms since 1990. The species could not be identified with certainty and will therefore subsequently be called Planktothrix sp. Whitefish (Coregonus lavaretus) is the dominant fish species having great importance for the local fishing industry.

In 1990, coregonid hatchlings from hatcheries in Lake Ammersee died within a 24-hour period during a bloom of Planktothrix sp., accompanied by metalimnic oxygen levels of $1 \mathrm{mg} / \mathrm{l}$. For 10 years, developing corego- 
nids have shown massive reduction in body weight and were in poor physiological condition (Wißmath et al., 1993; Negele et al., 2000). Whole age groups of the coregonid population have disappeared and till date, as a result of the total absence of 1997 and 1998 classes of coregonids, the fishery lies fallow. The causes for this, however, remain unclear.

During a Planktothrix sp. bloom episode in summer 1998, gut contents of whitefish displayed a blue discoloration, probably representing phycobiliproteins typical of cyanobacterial ingestion (Carbis et al., 1996). Planktothrix sp. is known to produce the cyclic peptide toxin desmethyl microcystin-RR (microcystin dmRR) (Lindholm and Meriluoto, 1991; Luukkainen et al., 1993). Previous studies have shown effects of hepatotoxic cyanobacteria on fish behaviour, development and, growth (Beveridge et al., 1993; Oberemm et al., 1999) as well as establishing a link between cyanobacteria blooms and acute fish mortality (Nascimento et al., 1999; Berg et al., 1986). Therefore, the aim of this study was to elucidate the possible effects of Planktothrix sp. blooms on coregonid population dynamics in Lake Ammersee.

\section{MATERIALS AND METHODS}

\section{Sampling of Cyanobacteria, Water and Whitefish}

Samples were generally taken at two sites in Lake Ammersee: Breitbrunn and Riederau. Cyanobacterial samples were collected in August and November 1998 and from April 1999 to December 1999 from Lake Ammersee using a $40 \mu \mathrm{m}$ gauze net. One clone of Planktothrix sp. was isolated from a sample in November 1998 and cultivated in BG 11 media according to Rippka et al. (1979). Taxonomy of fresh samples was determined using light microscopy and classified according to Anagnostidis and Komarek (1988). Samples were stored at $-20^{\circ} \mathrm{C}$.

Water samples were taken at various depths between 0 and $40 \mathrm{~m}$ at weekly intervals from April to November 1999, in July 2000 and from October 2000 to May 2001. Abundance of Planktothrix sp. was qualitatively quantified in these water samples using epifluorescence microscopy adapted from Walsby and Avery (1996) and image processing (Visiometrix IPS, Germany).

Furthermore, water samples $(500 \mathrm{ml})$ were taken from 3, 5, 7 and $9 \mathrm{~m}$ depth every month from August to December 1999. The samples were mixed and used for toxin analyses. In August 1999, an additional sample profile was taken between 0 and $40 \mathrm{~m}$ depth. Water was filtered $(0.2 \mu \mathrm{m})$, purified by solid phase extraction using I-solute C18 end-capped SPE cartridges (International Sorbent Technology, UK) and stored at $-20^{\circ} \mathrm{C}$.
Fish samples from catches of local fishermen, were taken in August and November 1998 as well as in April and August 1999. Organs and gut content were prepared and stored at $-20^{\circ} \mathrm{C}$.

Samples were taken in the Lake Ammersee hatchery in April 1999 and December 2000 to April 2001. Water samples were taken for Planktothrix sp. cell counts and microcystin analyses. Whitefish eggs and larvae were obtained and studied for developmental progress.

\section{Extraction of Cyanobacteria and Gut Contents}

Samples were freeze-dried. Extracts were obtained by sonication in $100 \%$ methanol $(60 \mathrm{~min})$ and subsequent centrifugation $(68,000 \mathrm{~g}, 60 \mathrm{~min})$. Methanol was removed via speed-vac centrifugation and the final extract was taken up in a defined volume of Milli-Q water. Extracts of cyanobacteria and gut content were analysed using ELISA, protein-phosphatase-inhibition assay (PPA), MTT assay and HPLC. For HPLC analysis, extracts were further purified by solid phase extraction using Isolute C18 end-capped SPE cartridges. Isolation of rainbow trout hepatocytes was adapted from Ostrander et al. (1995).

\section{Determination of Toxicity}

The 1998 bloom sample was tested for cytotoxicity in isolated trout hepatocytes using the standard MTT assay. The assay measures the activity of the mitochondrial succinate-tetrazolium reductase system, which is active only in viable cells.

The protein phosphatase inhibition assay including an acid molybdate extraction of inorganic phosphate was performed according to MacKintosh (1993). Microcystin-dmRR was used as standard. External standards were prepared for microcystin-LR, microcystinYR, Nodularin (all Calbiochem, USA), microcystinRR (Sigma, Germany) and for microcystin-dmRR and microcystin-dmLR (provided by J. Meriluoto, Turku, Finland) at different concentrations each $(1-50 \mu \mathrm{g} / \mathrm{ml})$. Extracts were subjected to HPLC (Beckman Ultrasphere ODS-column $(250 \times 4.6 \mathrm{~mm}, 5 \mu \mathrm{m}))$, with Acetonitril/0,0135 $\mathrm{M}$ ammonium acetate $(27 \% / 73 \%)$ as mobile phase. Sample peaks showing similar retention times to external standards were collected and their UV spectra (200-300 nm) and mass spectra were measured. Peak area and peak height were compared to external standard.

\section{Detection of Microcystin}

Liver tissue was homogenised in extraction buffer containing $1 \mathrm{mM}$ PMSF, $5 \mathrm{mM}$ EDTA, $1 \mathrm{mM}$ DTT, $140 \mathrm{mM}$ 
$\mathrm{NaCl}, 1 \%$ Triton $\mathrm{X}-100$ and $10 \mathrm{mM}$ Tris (pH 7.5). Proteins were separated using SDS-Page and Western Blot according to Laemmli (1970). Microcystin was detected using polyclonal anti-ADDA antiserum (Fischer 1999). Secondary antibody binding was determined by AECchromogen (BioGenex).

Microcystin was detected in gut contents and water samples by competitive ELISA adapted from Fischer et al. (2001) with anti-ADDA antiserum and protein phosphatase inhibition assay.

\section{RESULTS}

\section{Abundance, Toxin Composition and Toxin Contents}

Planktothrix sp. was detectable in samples of Lake Ammersee from August 1998 to May 2001. In 1999, the highest density was observed in the metalimnic layer during summer stratification in July, with more than 20,000 cells $/ \mathrm{ml}$ (Fig. 1). At the same time, few Planktothrix filaments were detected in the epilimnic layer. In 2000, the highest density was observed in the epilimnic layer in December, with 80,000 cells/ml.

HPLC analyses of extracts from Planktothrix sp. samples showed four peaks with similar retention times to external standards. Mass- and UV-spectra proved conformity of sample peaks to standards. MicrocystindmRR was the main toxin component with a 10 -fold higher concentration than microcystin-LR, microcystinRR and microcystin-dmLR.

Microcystin was detectable in Planktothrix extracts from August and November 1998 as well as from April

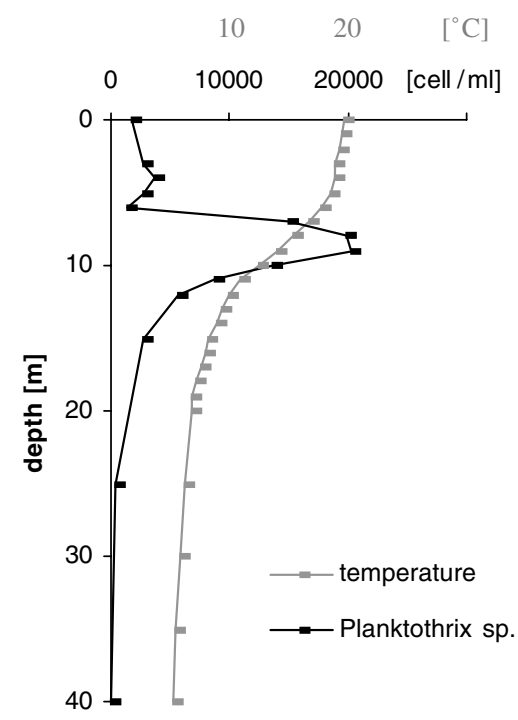

Fig. 1. Distribution of Planktothrix sp. in Lake Ammersee water column in July 1999.
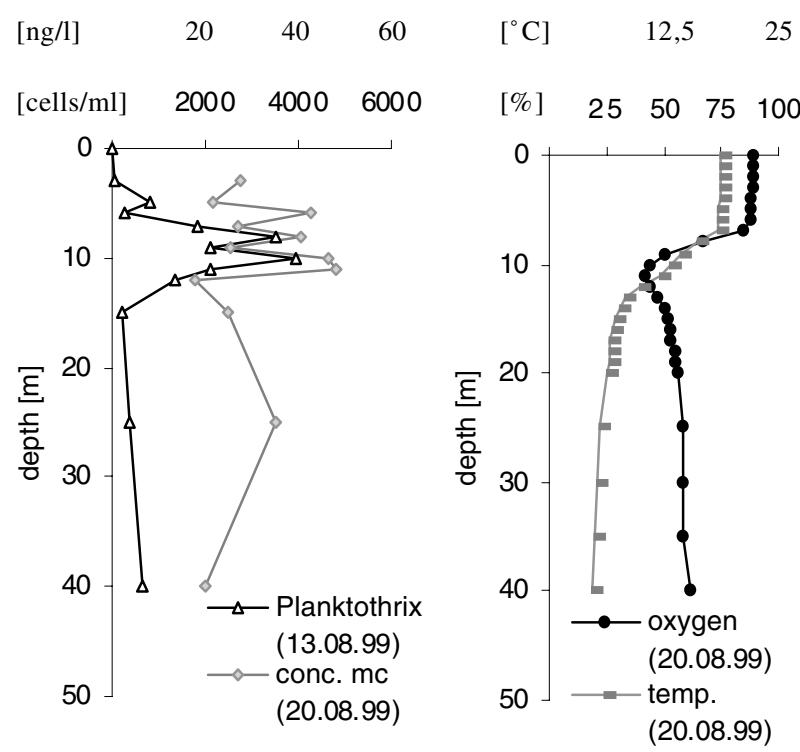

Fig. 2. Distribution of Planktothrix sp. at Riederau, Lake Ammersee. The distribution correlated with the microcystin concentration in the subsequent week. Simultaneously, a decrease of dissolved oxygen in the meta- and hypolimnic layers was observed.

to December 1999. Highest concentrations were measured in samples of 1998 and from July, August and October 1999 with amounts of 3-6.5 $\mu \mathrm{g} / \mathrm{mg}$ dry weight. Lowest concentrations were measured in April, May, June and November 1999 with concentrations between 0.5 and $1 \mu \mathrm{g} / \mathrm{mg}$.

Microcystins were detected in water samples from August to December 1999. In September and December, amounts of 66 and $78 \mathrm{ng} / \mathrm{l}$ were determined. Three microcystin peaks were detected in the sample profile of the water column of August 20, 1999 with a concentration of more than $40 \mathrm{ng} / \mathrm{l}$. The peaks in 3$15 \mathrm{~m}$ depth correlated to Planktothrix distribution in the water column of the previous week. In addition, another peak at $25 \mathrm{~m}$ depth was found having a microcystin concentration of $35 \mathrm{ng} / \mathrm{l}$.

Simultaneous to the Planktothrix distribution in the water column, oxygen saturation decreased to less than $60 \%$ between 9 and $40 \mathrm{~m}$ depth. Lowest oxygen levels were determined in the metalimnic layer (9-15 m) with a saturation of less than $50 \%$ (Fig. 2).

\section{Toxicity}

An extract of a Planktothrix bloom sample from August 1998 (67 mg lyophilisate/ml) caused a significant reduction in hepatocyte viability and protein-phosphatase activity.

The viability of trout hepatocytes was reduced to $69 \%$ compared to controls $(n=4$; Student's $t$-test; $p<0.05)$. In addition, the same extract showed strong 
protein-phosphatase inhibition. Extract in 1000-fold dilution decreased activity of protein phosphatase to $30 \%(n=4$; Student's $t$-test; $p<0.001)$.

\section{Fish Samples}

Planktothrix filaments were observed in blue-coloured gut contents of Lake Ammersee whitefish during the bloom episode in August 1998. Histological studies, prepared in the Bayer. Landesamt $\mathrm{f}$. Wasserwirtschaft, Wielenbach marked histopathological changes in gut tissue of Lake Ammersee whitefish caught during this bloom. Disintegration of tissue structure and high erythrocyte and leukocyte cell counts could be observed. Furthermore, gut contents had microcystin amounts between 5 and $35 \mathrm{ng} / \mathrm{mg}$ dry weight during the bloom episode. Four samples had significantly higher amounts than gut content of control coregonids from Lake Constance (Fig. 3).

In 1999, local fishermen caught whitefish in areas of high Planktothrix density from May to August. Microcystin protein-adducts were detected in liver tissue of Lake Ammersee whitefish in August 1998 and 1999 with characteristic molecular weights between 28 and $39 \mathrm{kD}$ (Fig. 4).

\section{Observations in Lake Ammersee Hatchery}

Planktothrix filaments as well as microcystin were detectable in hatchery water during the whole embryonic development in winter 2000/2001.

Whitefish eggs and larvae, obtained during bloom episodes in winter 1997/98 and 2000/01 in Lake

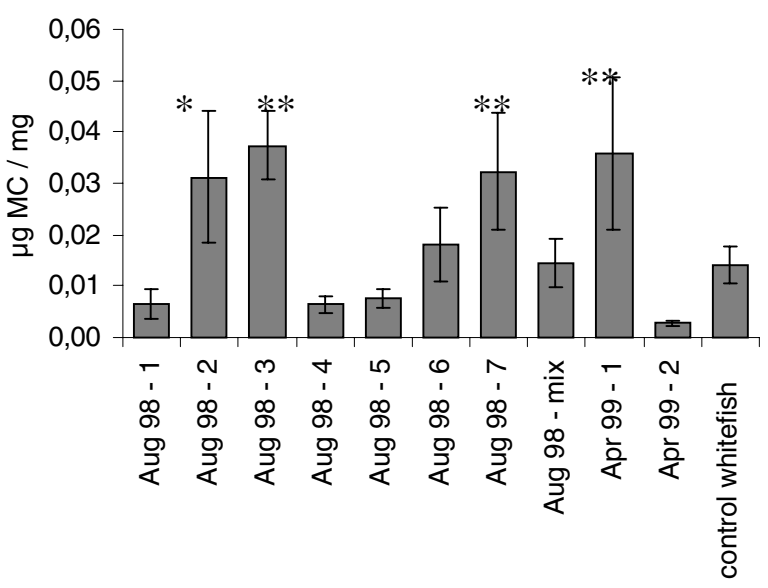

Fig. 3. Amount of microcystin in blue-coloured gut contents of Lake Ammersee whitefish caught during a Planktothrix bloom episode in 1998 (error bars $=95 \% \mathrm{Cl}, \mathrm{n}=10$; Statistics by ANOVA, followed by a Dunnetts Multiple Comparison test; significant difference to control whitefish; * $p<0.05$, $\left.{ }^{* *} p<0.01\right)$.

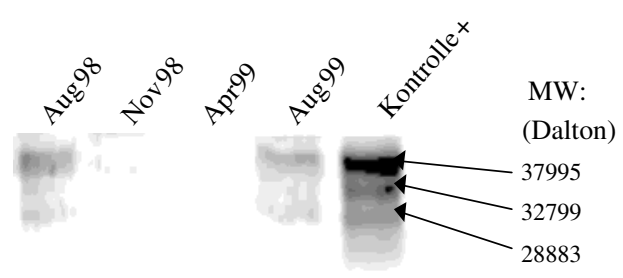

Fig. 4. Detection of microcystin-binding-protein adducts in liver homogenates of Lake Ammersee coregonids by immunoblotting. Samples of August 1998 and 1999 showed bands with a characteristic molecular weight of $38 \mathrm{kD}$.

Ammersee hatchery showed malformations, which are typical for cyanobacterial toxin exposure. In winter 2000/2001, nearly $75 \%$ of whitefish eggs died before hatching in Lake Ammersee hatchery.

\section{DISCUSSION}

Previous descriptions of cyanobacteria-associated fish kills display similar characteristics to those observed in the mortality of coregonid fry from Lake Ammersee in 1990, including coincident high levels of Planktothrix sp. and extremely low oxygen levels (Wißmath et al., 1993; Nascimento et al., 1999).

Low metalimnic oxygen levels as well as the simultaneous predominance of Planktothrix sp. have occurred in Lake Ammersee since 1990 (Wißmath et al., 1993; Lenhart 2000). The microcystin peaks concurred with low oxygen levels in August 1999. This probably marked a degradation of Planktothrix filaments in the metaand hypolimnic layers, which resulted in cell lysis and decreasing oxygen levels. Therefore, the low metalimnic oxygen levels appeared to be connected to the abundance of Planktothrix sp. in Lake Ammersee as described for other lakes earlier (Sivonen et al., 1990; Lindholm et al., 1991).

Acute toxicity of cyanobacterial samples, histopathological changes in gut tissue and detection of microcystin in liver tissue and gut contents of fish from August 1998 showed that toxic Planktothrix sp. may affect Lake Ammersee coregonids. This effect seemed to be strongest during summer stratification, when high Planktothrix sp. cell densities and microcystin levels occur in the main habitat of coregonids.

Protein phosphatases (PP) are important regulatory enzymes in the metabolism of eukaryotes. Therefore, PP inhibition by microcystin may have serious effects on metabolism of fish leading, for example, to decreasing glycogen synthesis (Falconer 1993; Runnegar 1987). Unfavourable physiological condition of Lake Ammersee coregonids (Wißmath et al., 1993; Negele 
et al., 2000) could therefore be an effect of microcystin intoxication. Further factors must also be considered, including the low metalimnic oxygen levels and avoidance behaviour to cyanobacteria. Examples for this are the migration of whitefish from metalimnic layer to colder depths with less favourable food resources as observed in former studies (Wißmath et al., 1993) or decreasing filtration rates of planktivore coregonids as described for other planktivore fish species (Beveridge et al., 1993).

The observation of high Planktothrix sp. densities and microcystin in the Lake Ammersee hatchery concurrent with high Planktothrix sp. cell densities up to $80 \mathrm{~m}$ depth in circulating lake water during the winter 2000/01 may lead to malformations in whitefish eggs and larvae in the hatchery as well as in natural habitats. The fact that the observed malformations are comparable to those observed in previous studies (Oberemm et al., 1999) corroborates this theory. The observed disappearance of coregonid age-groups may be a result of these developmental effects of the cyanobacterial toxins. The results of this investigation have to be viewed in conjunction with the recent Brazilian observations that consumption of fish contaminated with microcystins can lead to an exceeding of the TDI drinking water guideline of $0.04 \mu \mathrm{g} / \mathrm{kg}$ body weight/day (Freitas de Magalhaes et al., 2001).

In summary, the dominance of the toxic cyanobacteria Planktothrix sp. since 1990 (Lenhart, 2000) appears to be a main cause for irregularities in development and growth of coregonids in Lake Ammersee.

We thank R.D. Negele (Bayer. Landesamt f. Wasserwirtschaft) for generously providing histological samples, W. Hofer (University of Konstanz) for providing ${ }^{32} \mathrm{P}-\mathrm{ATP}, \mathrm{J}$. Meriluoto (Åbo Akademi, Turku, Finland) for generously providing desmethyl-MC standards and B. Day (University of Pittsburgh) for measuring sample mass-spectra. Further we thank K.O. Rothaupt and E. von Elert (University of Konstanz) for generously enabling the use of their analytical apparatus and their help in discussing limnological problems.

\section{REFERENCES}

Anagnostides K, Komarek J. 1988. Modern approach to the classification of cyanophytes. Arch Hydrobiol Suppl 80:327-472.

Berg K, Skulberg OM, Skulberg R, Underdal B, Willen T. 1986. Observation on toxic blue-green algae (cyanobacteria) in some Scaninavian lakes. Acta vet scand 27:440-452.

Beveridge MCM, Baird DJ, Rahmatullah SM, Lawton LA, Beattie KA, Codd GA. 1993. Grazing rates on toxic and non toxic stains of cyanobacteria by Hypopthalmichthys molitrix and Oreochromis niloticus. J Fish Biol 43(6):901-907.
Carbis C, Rawlin GT, Mitchell GF, Anderson JW, McCauley I. 1996. The histopathology of carp, Cyprinus carpio L., exposed to microcystin by gavage, immersion and intraperitoneal administration. J Fish Diseases 19:199-207.

Falconer IR. 1993. Mechanism of toxicity of cyclic peptide toxins from blue green algae. In: Algal Toxins in Seafood and Drinking Water. New York: Academic Press Chapter 11.

Fischer WJ. 1999. Investigation into the enviromental impact of cyanobacterial cyclic peptide toxins. PhD Thesis, University of Konstanz.

Fischer WJ, Garthwaite I, Miles CO, Ross KM, Aggen JB, Chamberlin R, Towers NR, Dietrich DR. 2001. A congenerindependent immunoassay for microcystins and nodularins. Environ Sci Technol in press.

Freitas de Magalhaes V, Soares RM, Azevedo SMFO. 2001. Microcystin contamination in fish from the Jacarepagua Lagoon (Rio de Janeiro, Brasil) Toxicon 39: 1077-1085.

Laemmli U. 1970. Cleavage of structural proteins during assambly of the head of bacteriphage. Nature 227: 680-685.

Lenhart B. 2000. Langfristige Entwicklungen-Eutrophierung und Reoligotrophierung-am Ammersee. Münchner Beiträge zur Abwasser Fischerei und Flussbiologie 53: 97-114.

Lindholm T, Meriluoto JAO. 1991. Reccurent depth maxima of the hepatotoxic Cyanobacterium Oscillatoria agardhii. Can J Fish Aquat Sci 48:1629-1634.

Luukkainen R, Sivonen K, Namikoshi M, Färdig M, Rinehart KL, Niemelä SI. 1993. Isolation and identification of eight microcystins from thirteen Oscillatoria agardhii strains and structure of a new microcystin. Appl Environ Microbiol 59(7):2204-2209.

MacKintosh C. 1993. Protein phosphorylation: A practical approach. Oxford: Oxford University Press. 197-229.

Nascimento SM, de Oliveira e Azevedo SM. 1999. Changes in cellular components in a cyanobacteria (Synechocystis aquatilis $\mathrm{f}$. salina) subjected to different N/P Ratios-An Ecophysiological Study. Environ Toxicol 14:37-44.

Negele RD, Braunbeck T, Berbner T, Schwaiger J, Mallow U, Ferling H, Ott B. 2000. Licht und Elektronenmikroskopische Untersuchungen an Fischlebern zur Beurteilung des Gesundheitszustandes von Renken aus dem Ammersee. Münchner Beiträge zur Abwasser Fischerei und Flussbiologie 53:245-281.

Oberemm A, Becker J, Codd JA, Steinberg C. 1999. Effects of cyanobacterial toxins and aqueous crude extracts of cyanobacteria on the development of fish and amphibians. Environ Toxicol 14:77-88.

Ostrander G, Blair J, Stark B, Marley G, Bales W, Veltri R, Hinton D, Okihiro M, Ortego L, Hawkins W. 1995. Long term primary culture of epithelial cells from rainbow trout (Oncorhynchus mykiss) liver. In Vitro Cellular Dev Bio 31:367-378.

Rippka R, Deruelles J, Waterbury JB, Herdman M, Stanier RY. 1979. Generic assignments strain histories and proper- 
ties of pure cultures of cyanobacteria. J General Microbiol 111:1-61.

Runnegar MTC, Andrews J, Gerdes RG, Falconer IR. 1987. Injury to hepatocytes induces by a peptide toxin from the cyanobacterium Microcystis aeruginosa. Toxicon 25:1235-1239.

Sivonen K, Niemelä SI, Niemi RM, Lepistö L, Luoma TH, Räsänen LA. 1990. Toxic cyanobacteria (blue green algae) in Finish fresh and coastal waters. Hydrobiologia. 190:267-275.

Walsby AE, Avery A. 1996. Measurement of filamentous cyanobacteria by image processing analysis. J Microbiol Methods 26:11-20.

Wißmath P, Limburg U, Wunner U, Huber B. 1993. Das Ammersee Syndrom. Fischer \& Teichwirt 3:78-87. 